\title{
After zigzagging between extremes, finally common sense? Will Belgium return to reasonable rules on illegally obtained evidence?
}

Depois de ziguezaguear entre os extremos, finalmente senso comum? Bélgica retornará às regras razoáveis sobre ilicitude probatória?

\section{Frank Verbruggen ${ }^{1}$}

KU Leuven, Belgium

frank.verbruggen@kuleuven.be

https://orcid.org/0000-0001-5916-7495

\section{Charlotte Conings ${ }^{2}$}

KU Leuven, Belgium

charlotte.conings@stibbe.com

https://orcid.org/0000-0002-5901-6790

"Just as every cop is a criminal

And all the sinners saints

As heads is tails Just call me Lucifer

"Cause I'm in need of some restraint" (The Rolling Stones - Sympathy for the Devil)

\begin{abstract}
АвSTRACt: In the absence of statutory rules on the matter, Belgian courts traditionally applied a strict exclusionary rule for illegally gathered evidence and its fruits. The Court of Cassation in 2003 made a spectacular U-turn and prohibited exclusion of illegally obtained evidence by criminal courts, with only very limited exceptions. Parliament subsequently incorporated these judge-made principles
\end{abstract}

1 Professor at the Institute of Criminal Law (KU Leuven). Doctor in Law.

2 Doctor in Law, Lawyer at Stibbe Brussels and Voluntary Academic Assistant at the Institute of Criminal Law (KU Leuven). 
into a binding statutory rule. As a new Code is about to be debated in Parliament, the time is right to question the "normalisation" of law enforcement officers' disrespect for the rules. The Rule of Law will be restored by making exclusion of illegally gathered evidence the rule, but exceptionally allowing its use upon consideration of the conflicting interests.

Keywords: Illegally obtained evidence; Admissibility; Fair trial; Exclusionary rule; Codification.

Resumo: Diante da omissão de normas sobre a questão, as cortes belgas tradicionalmente aplicavam regras rígidas de exclusão de provas obtidas ilegalmente e suas derivadas. A Corte de Cassação em 2003 alterou drasticamente tal posição e proibiu os tribunais de excluir as provas ilícitas, salvo exceções bastante limitadas. O Legislativo então incorporou esses princípios em uma regra legal obrigatória. Considerando os debates legislativos sobre um novo código, o momento é adequado para discutir a normalização do desrespeito às regras pelos agentes estatais. O Estado de Direito será restaurado com a consolidação da regra de exclusão das provas ilícitas, mas com a possibilidade de utilização excepcional a partir de ponderação de conflito de interesses.

Palavras-chave: provas ilícitas; admissibilidade; justo processo; regra de exclusão; codificação.

\section{INTRODUCTION: THE END OF THE NAPOLEONIC ERA}

Napoleon Bonaparte introduced a series of codes, but the Code of Criminal Procedure (1808) has never been considered a highlight. ${ }^{3}$ Upon gaining independence in the 19th Century, Belgium kept using this French Code with the intention of replacing it by one of its own: a Belgian code. ${ }^{4}$ In 2020 , it still has that intention... Of course, the 'Napoleonic' Belgian Code

3 C. Van Den Wyngaert, P. Traest, S. Vandromme, Strafrecht en strafprocesrecht, Antwerpen, Maklu, 2017, 13.

4 J. Monballyu, Zes eeuwen strafrecht, de geschiedenis van het Belgische strafrecht (1400-2000) (Six Centuries of Criminal Law, the History of Belgian Criminal Law (1400-2000)), Leuven, Acco, 2006, 47-55. 
of Criminal Procedure (CCP) has undergone many changes, very often under pressure of the European Court of Human Rights, which insists on an explicit and specific legal base for government intrusion upon citizens' rights. The matter of evidence was hardly regulated by the old code and the European Court of Human Rights has always been quite reluctant to seem to be interfering too much. ${ }^{5}$ Hence the matter was left to Belgian courts and doctrine. In the early $21^{\text {st }}$ Century the highest court in the criminal justice system, the Court of Cassation, made a remarkable U-turn on the exclusionary rule for illegally obtained evidence. Except in very rare situations, courts are now obliged to use illegal evidence. Parliament codified this rule in 2013. This contribution is mainly a description for foreign readers of the remarkable Belgian situation. Upon a request from the Belgian government, an expert committee has, however, issued a draft for a new code and Parliament is expected to start discussing it in 2021. It proposes an adjustment of the statutory rules on this fundamental issue. Hence we end with some personal reflections on this proposal. ${ }^{6}$.

5 It uses the standard clause that Article 6 E.C.H.R. "does not lay down any rules on the admissibility of evidence as such, which is primarily a matter for the regulation under national law. It is not for the Court to determine particular types of evidence -for example, evidence obtained unlawfully in terms of domestic law -may be admissible. The question which must be answered is whether the proceedings as a whole, including the way in which the evidence was gathered were fair." (ECtHR (Grand Chamber) 10 March 2009, n.4378/02, Bykov/ Russia, § 88, see also ECtHR 12 July 1988, Series A no. 140, Schenk/ Switzerland, § 45; ECtHR 9 June 1998, Reports 1998-IV, Teixeira de Castro/ Portugal, § 34).

6 This is a somewhat subjective, we would say 'principled but pragmatic' approach. It is based on our belief that both the absolute exclusionary rule and its opposite (the compulsory maximal use of illegally gathered evidence to convict suspects) fail to strike a proper balance between the conflicting interests at stake. For a legal system to be coherent, the principle is that rules should be applied and exceptions to that principle require a justification that can be checked. However, the 'rules to be applied as much as possible' do not only cover the rules of procedure to be respected by law enforcement, but also the substantive criminal law to be enforced. That entails a complex balancing act. We wonder which use of an exclusionary rule would lead to a 'maximal application of the rules'. The crux is that we think that statutory law should indicate which interests should be taken into account, but that, except for extreme situations like torture, the judge of the facts is best placed to consider the appropriate balance in the specific case (infra). 


\section{General Principles of Belgian Criminal Procedural Law}

The Belgian legal system is embedded in a civil law tradition. Statutory legislation is the main source of law for both criminal law and criminal procedure. The system is mainly inquisitorial, although the number of accusatorial features is increasing. The pre-trial stage is still characterised by its mainly secret and inquisitorial nature, while the trial stage is public and the principles of adversarial argument apply.

At the pre-trial stage, two types of investigations can be distinguished: the preliminary investigation and the judicial inquiry. A preliminary investigation is led by the public prosecutor, a judicial inquiry by an (impartial and independent) investigating judge under the supervision of the Indictment Chamber of the Court of Appeal. A judicial inquiry is required as soon as a victim files a civil complaint with the investigating judge or when an investigative measure has to be carried out that belongs to the sole competence of the investigating judge. Measures belonging to the sole competence of the investigating judge are typically measures which are considered very privacy-intrusive and far-reaching (e.g. home searches, wiretaps, covert computer searches, ...). However, privacy-intrusive measures are increasingly shifting towards the public prosecutor's office. The investigating judge can authorise any measure that the public prosecutor may also authorise. The vast majority of the criminal cases (approximately 95\%) is however dealt with by means of a preliminary investigation.

Since the procedural regime in case of a judicial inquiry is burdensome and entails an especially complex procedure at the end of the investigative stage, Parliament introduced a simplified intermediate procedure called the "mini judicial inquiry" (art. 28septies CCP). In this procedure the intervention of the investigating judge is limited to a oneoff authorisation (or refusal) to carry out an investigative measure. As a result, an increasing amount of investigative measures belonging to the exclusive competence of the investigating judge no longer require the start of a judicial inquiry: in spite of the use of the intrusive measure, the investigation remains with the public prosecutor. Nevertheless, even if the public prosecutor only filed a limited request for such a mini judicial inquiry, the investigating judge always retains the option of taking over the 
whole investigation and starting a judicial inquiry. Additionally, certain specific investigative measures are excluded from the mini judicial inquiry and thus always require a judicial inquiry. ${ }^{7}$

Under the principle of equality of arms, the parties are granted access to all evidence that has been collected, at the latest once the investigation is completed. This ensures the fairness of the proceedings and allows the parties to prepare their case. In more general terms, the prosecution should add all elements to the case file which could be relevant to establish the truth about what happened. ${ }^{8}$ Law enforcement authorities should also be sufficiently transparent about how they conducted their investigation, about its results and how the evidence encountered has been handled. In the investigation phase, the procedure is essentially a written one. Law enforcement officers write official reports on the investigation measures they carry out and must include them in the case file. However, Belgian law lacks general statutory provisions on which information should be included in the official report. ${ }^{9}$ Adequate transparency is required, to allow the parties to the proceedings to verify the reliability of the evidence and the legality of the investigation and to raise potential problems before the court. ${ }^{10}$

Belgium has rather few explicit rules on assessment of evidence. Once evidence is allowed in court, judges can freely assess the reliability and weight of the evidence put before them and are only bound by their 'deep-down conviction' (innerlijke overtuiging - l'intime conviction). ${ }^{11}$ Specific exceptions to the free assessment of evidence are rare. The following types of evidence should be sufficiently corroborated by

7 Such as a home search (Constitutional Court 21 December 2017, $\mathrm{n}^{\circ}$ 148/2017).

8 Court of Cassation 30 October 2001, AR P.01.1239.N, Arr. Cass. 2001, 1815.

9 C.Conings, Klassiek en digitaal speuren naar strafrechtelijk bewijs, Antwerp, Intersentia, 2017, 360-361; T. Decaigny, Tegenspraak in het vooronderzoek, Antwerpen, Intersentia, 2013, 361.

10 An important difference exists between evidence and police information which is only used to start or direct the investigation. Infra Evidence vs. police information.

11 S. De Decker, F. Verbruggen, “Across the River and Into the Poisonous Trees. From exclusion to the Use of Illegally Gathered Evidence in Criminal Proceedings in Belgium", in The XIIIth World Congress of Procedural Law: the Belgian and Dutch Reports, Antwerpen, Intersentia, 2008, 65. 
additional elements of proof: statements of anonymous witnesses ${ }^{12}$, statements made by teleconference ${ }^{13}$, statements of an offender assisting the authorities ('rewarded turncoat") ${ }^{14}$, the results of a polygraph test ${ }^{15}$ and evidence obtained via a civilian undercover agent ${ }^{16}$. The principle of free assessment concerns the probative value, it does not allow the judge to alter the content of the evidence or official reports in the case file. ${ }^{17}$

\section{Definition Illegally Obtained Evidence}

\section{Illegality}

If a judge is confronted with illegally obtained evidence, the question arises whether such evidence is admissible in court. Before answering this question, we will clarify under which circumstances evidence is considered to be 'obtained illegally'. The Court of Cassation clearly defined 'illegally obtained evidence' in 2004. ${ }^{18}$ Evidence is considered illegal if it has been gathered (i) by committing an offence, (ii) in violation of criminal procedural law, (iii) in violation of the right to privacy (art. 8 ECHR), (iv) in violation of the rights of the defence (art. 6 ECHR) or (v) in violation of the right to human dignity. The grounds of illegality are often interchangeable. For instance, most offences will infringe upon criminal procedural legislation, violations of human dignity will often be covered by a criminal offence and most infringements upon

12 Art. 189bis CCP.

13 Art. 112bis $\$ 6$ CCP.

14 Art. 216/4 CCP.

15 Art. 112duodecies §10 CCP.

16 I.e. not a sworn police officer, especially trained for such missions: Art. 47novies/3 §3 CCP.

17 S. De Decker, F. Verbruggen, “Across the River and Into the Poisonous Trees. From exclusion to the Use of Illegally Gathered Evidence in Criminal Proceedings in Belgium", in The XIIIth World Congress of Procedural Law: the Belgian and Dutch Reports, Antwerpen, Intersentia, 2008, 65.

18 Court of Cassation decision of 23 March 2004, AR P.04.0012.N, RABG 2004, 1061, with comment by F. Schuermans as confirmed in Court of Cassation decision of 21 November 2006, AR P.06.0806.N. 
criminal procedural law will also entail a violation of the right to privacy since the interference with private law will not be in accordance with the law as required by article 8 ECHR

The category of violation of criminal procedure legislation is furthermore not limited to specific formal rules of procedure. The prosecutor and investigating judge have a statutory duty to safeguard the loyalty or integrity of the evidence gathering process. ${ }^{19}$ Evidence gathered in a disloyal manner must be considered as 'illegally obtained', e.g. when a formal procedure is deliberately averted from its purpose to render illegally obtained evidence legal ('evidence laundering', a pretended 'accidental' discovery of evidence which was actually 'staged' ${ }^{20}$ or when the entire criminal investigation is based on the assumption that someone is guilty of an offence ${ }^{21}$. The latter situation will of course also run afoul of the presumption of innocence and will thus be in breach of the right to a fair trial.

Electronic evidence can be altered easily and is very volatile by nature. Yet Belgian law lacks specific technical rules on how it should be gathered and treated. Rules do exist on the circumstances in which law enforcement agencies can access electronic evidence, but there is no detailed legal regime for technical requirements regarding the execution of a search for digital evidence, nor clear requirements regarding the tools which may be used to perform such searches. Criminal procedural law only refers to 'suitable technical means' 22 , which should be used to gather and preserve digital evidence to ensure its integrity and confidentiality. Guidelines seem to exist at the level of the public prosecutors' office and police forces but they are not accessible to the public. ${ }^{23}$ The statutory

19 Art. 28bis in fine CCP and art. 56 CCP.

20 Brussels 10 December 2010, JT 2011, 54; Corr. Brussels 8 December 2009, JT 2010, 6-13, with comment.

21 Mons 26 november 2014, JT 2015, n. 6607, 467.

22 Art. 39bis §8 CCP and 90septies §1 CCP.

23 J. Kerhofs, P. Van Linthout, Cybercrime 3.0, Brussels, Politeia, 2019, 235. Guidelines also exist at the European level. The Electronic Evidence Guide, which has been created at the level of the Council of Europe is a basic guide for police officers, prosecutors and judges containing guidelines on the handling of digital evidence in all phases of the criminal investigation, prosecution 
requirement to use 'suitable technical means' entails that if a judge deems the specific technical tools used be the investigators 'unsuitable', e.g. when electronic data are altered while executing a search (such as when the configuration of the computer system under investigation is changed), the evidence will have been 'illegally obtained'. This will inevitably entail difficult factual and technical discussions.

\section{ILLEGALITY: COMMITTED BY WHOM? ${ }^{24}$}

Evidence is not only considered to be have been obtained illegally when the criminal prosecution authorities engaged in the illegal action. Illegal gathering of evidence by a private person may also affect its use in a criminal procedure. The Court of Cassation, however, only considers such evidence as 'illegally obtained' if two conditions are met: (i) the person who committed the illegality is the one who reported the offence to the law enforcement authorities and (ii) he or she engaged in the illegal action to obtain goods or information with the intention of using it as evidence in a criminal case. ${ }^{25}$

If the person who reported the offence to the authorities came across the data or goods by accident - albeit in an illegal manner, e.g. by burglary - said data or goods will not be considered 'illegally obtained' and can therefore simply be used as evidence in a criminal case. ${ }^{26}$ The same is true for the data or goods that were handed over

and during trial. It is based on best practices and national and international standards in the countries which are a party to the Cybercrime Convention. The guide is available at https://rm.coe.int/09000016809efd7f.

${ }_{24}$ S. De Decker, F. Verbruggen, "Across the River and Into the Poisonous Trees. From exclusion to the Use of Illegally Gathered Evidence in Criminal Proceedings in Belgium", in The XIIIth World Congress of Procedural Law: the Belgian and Dutch Reports, Antwerpen, Intersentia, 2008, 70-71; R.Verstraeten, Handboek Strafvordering, Antwerpen, Maklu, 2012, 987-988.

25 Court of Cassation decision of 17 January 1990, Arr.Cass. 1989-90, no. 310; Court of Cassation decision of 23 March 2004, AR P.04.0012.N, RABG 2004, 1061, with comment by F. Schuermans; Court of Cassation decision of 21 November 2006, AR P.06.0806.N.

26 Court of Cassation decision of 9 December 1997, $R W$ 1997-98, 1441. 
to law enforcement authorities by a person who was not involved in the illegal action. ${ }^{27}$

The Court also distinguishes between the actual illegal gathering of evidence and the mere illegal discovery of an offence. In the latter case, the person (including foreign authorities) who discovered the offence can report it to Belgian law enforcement authorities. This will not affect the legality of the evidence that is subsequently gathered by the Belgian law enforcement authorities. ${ }^{28}$

\section{EVIDENCE VS. POLICE INFORMATION}

In a broader sense Belgian courts distinguish illegally obtained evidence from 'police information' which is only used to start or direct the criminal investigation and is not used by the trial judge to establish his deep-down conviction on the existence of the offence or the criminal liability of the defendants. ${ }^{29}$

Evidence must always be subjected to judicial scrutiny ${ }^{30}$ and adversarial proceedings. By contrast, police information, i.e. information from police sources which the enforcement authorities do not (wish to) disclose and the exact origin of which is therefore typically unknown (informer, anonymous source, independent foreign investigation ${ }^{31}, \ldots$ ), will not be subjected to full judicial control on whether the procedural rules applicable to the gathering of such information have been respected. Police information can therefore only serve to launch the criminal investigation

27 Court of Cassation decision of 14 February 2001,JT 2001, 593; Court of Cassation decision of 18 May 2011,AR P.10.2049.F, ECLI:BE:CASS:2011:ARR.20110518.17. Court of Cassation decision of 30 May 1995, Arr. Cass. 1995, n. 267, JLMB 1998, 488, with comment by F. Kuty; Court of Cassation decision of 2 April 2008, AR P.07.1744.F, JT 2008, 390, with comment by F. Kuty; Court of Cassation decision of 18 May 2011, AR P.10.2049.F. $\mathrm{V}$. Vereecke, "Politionele informatie ontsnapt aan de Antigoon-toets" (comment on Court of Cassation decision 28 Februari 2017), T. Strafr. 2017, n. 4, 269.

30 F. Schuermans, "Cassatie bevestigt bijzonder statuut politionele aanvangsinformatie", Juristenkrant 2015, n. 306, 2.

31 Court of Cassation decision of 18 April 2017, AR P.16.1292.N, ECLI:BE:CASS:2017:ARR.20170418.12 . 
and steer its course. It can for instance help selecting places or persons as a target for surveillance or searches, whereas the actual evidence will only be gathered in the course of the surveillance or the search. In the same sense, the Court of Cassation has considered that "information gathered by the police that may give rise to further investigation is only ordinary information that must be verified by a preliminary or judicial investigation". ${ }^{32}$

Police information can only be challenged by defendants who can make it plausible that it has been obtained in an irregular manner. Mere ignorance of the origin of the information does not prevent it from being used to start or direct the investigation: that is not in itself sufficient to establish an irregularity. The Court of Cassation indeed held repeatedly that art. 6 ECHR does not preclude information of unknown origin from being taken into account as 'steering information', a basis for subsequent gathering of 'real' evidence, as long as it does not appear that the information has been gathered irregularly. ${ }^{33}$ This has been criticised as offering too much scope for 'evidence laundering'. ${ }^{34}$

When a defendant makes it plausible that the police information was gathered in an illegal way, the law enforcement authorities will have to clarify how the information was obtained. If they do not succeed in establishing the legal origin of the information, the judge will assume it has been obtained in an irregular way ${ }^{35}$. The rules on the use of illegally obtained evidence (threefold test, infra) do not apply to illegally obtained

32 Court of Cassation decision of 27 September 2016, AR P.15.0852.N, ECLI:BE:CASS:2016:ARR.20160927.3.

33 Court of Cassation decision 21 January 2003, AR P.01.1121.N; Court of Cassation decision 5 February 2013, AR P.12.0673.N; Court of Cassation decision 10 September 2013, P.13.0376.N; Court of Cassation decision 1 December 2015, AR P.15.0905.N, ECLI:BE:CASS:2015:ARR.20151201.4; Court of Cassation decision 27 September 2016, AR P.15.0852.N, ECLI:BE:CASS:2016:ARR.20160927.3. See also: F. Schuermans, "De zoektocht naar of de jacht op de oorsprong van de politionele informatie als start van een strafrechtelijk vooronderzoek", T. Strafr. 2014, n.1, 48.

34 That is why experts suggest abolishing this distinction, see paragraph VII. below.

35 V. Vereecke, "Politionele informatie ontsnapt aan de Antigoon-toets" (comment on Court of Cassation decision 28 Februari 2017), T. Strafr. 2017, n. 4, 270. 
police information. The judge only verifies whether the right to a fair trial would be violated if the police information is used. ${ }^{36}$

\section{USE OF ILLEGALLY OBTAINED EVIDENCE}

\section{From EXCLUSION to ADMISSION}

Traditionally (from the 1920s onwards) the courts and doctrine stressed that illegally obtained evidence could not be used in court against the suspect. ${ }^{37}$ From 2003 onwards, the Court of Cassation, however, drastically curtailed the exclusionary rule (developing the so-called Antigoon-theory) $)^{38}$, and actually turned the tables: it made exclusion of illegally obtained evidence the exception rather than the rule. On several occasions, the Constitutional Court has condoned this new approach. ${ }^{39}$

36 Court of Cassation decision 28 February 2017, AR P.16.0261.N, ECLI:BE:CASS:2017:ARR.20170228.3; Court of Cassation decision of 18 April 2017, AR P.16.1292.N, ECLI:BE:CASS:2017:ARR.20170418.12 (in relation to information coming from a foreign investigation).

37 Court of Cassation decision of 12 March 1923, Pas. 1923, I, 233; Court of Cassation decision of 10 December 1924, Pas. 1924, I, 66; Court of Cassation decision 8 January 1945, Pas. 1945, I, 81; Court of Cassation decision of 24 May 1948, $R W$ 1948-49, 51, with comment; Court of Cassation decision of 13 May 1986, AR 9136, Arr.Cass. 1985-86, 1230, concl. J. Du Jardin; Court of Cassation decision of 4 January 1994, AR 6388, Arr.Cass. 1994, 1, concl. J. Du Jardin, $R$. Cass. 1994, 75, with comment by P. Traest, $R W 1994-95$, 185, with comment by F. D'Hondt; Court of Cassation decision of 24 April 1996, AR P.96.0350.F, Arr.Cass. 1996, 334; Court of Cassation decision of 9 December 1997, AR P.97.1329.N, Arr.Cass. 1997, 1330; Court of Cassation decision of 23 December 1998, AR A.94.0001.F, Arr.Cass. 1998, 1166; Court of Cassation decision of 13 January 1999, AR P.98.0412.F, Arr.Cass. 1999, 28.

38 It owes its name to a legendary figure in Antwerp folklore who had provided the codename for the police action in the course of which the illegal gathering of evidence had happened: Court of Cassation decision of $14 \mathrm{Oc}-$ tober 2003, AR P.03.0762.N, Arr.Cass. 2003, 1862, RABG 2004, n. 6, 333, with comment by F. Schuermans, RCJB 2004, n. 4, 405, with comment by F. Kuty, $R W$ 2003-04, 814, concl. M. De Swaef, T.Strafr. 2004, n. 2, 129, with comment by P. Traest.

39 Constitutional Court 22 December 2010, n. 158/2010, B.7. It treated the issue in a remarkably succinct matter: after reminding that the European Court of Human Rights repeatedly had decided that the use of evidence was mainly a 
In 2004, the new approach was codified for the first time, but only in relation to evidence obtained abroad. ${ }^{40}$ In 2013, and once more without much legislative debate, a new article 32 was introduced in the Preliminary Title of the Code of Criminal Procedure (hereinafter: PT CCP), which codified the Antigoon doctrine.

Under art. 32 PT CCP the judge may declare illegally obtained evidence inadmissible only if:

(i) statute law explicitly mentions nullity as the sanction for neglecting the formality;

(ii) the irregularity affects the reliability of the evidence; or

(iii) the use of the illegally obtained evidence would violate the right to a fair trial.

Said three grounds for exclusion of evidence have to be considered as exclusive: only in the given three scenarios the evidence can and has to be excluded. ${ }^{41}$ As Maes points out ${ }^{42}$, neither the Court of Cassation, nor the drafters of article $32 \mathrm{CCP}$ have given theoretical reasons or invoked an explicit underlying vision on the function of the exclusionary rule to justify why it should be limited to these three grounds. The ratio, both behind the Court of Cassation's U-turn and Parliament's decision to codify it, seems to be an increasing irritation with suspects and defendants invoking

matter of member state law and that the use of evidence gathered in violation of article $8 \mathrm{ECHR}$ did not necessarily lead to a violation of article $6 \mathrm{ECHR}$, it stressed that the corresponding clauses in the Belgian constitution did not explicitly contain such a ban on the use of evidence either. An implicit ban in the constitution's article on the protection privacy was ruled out, because it was the intention of its framers to strive for maximal coherence between the fundamental rights protection under the Belgian constitution and that under the ECHR; see also: Constitutional Court 27 July 2011, n. 139/2011.

Art. 13 of the Statute of 9 December 2004 concerning mutual assistance in criminal matters, Official Bulletin 24 December 2004.

41 See in the same sense: Court of Cassation decision of 12 October 2005, AR P.05.0119.F., JT 2006, 109, JLMB 2006, 585, Pas. 2005, 1904, Rev.dr.pén. 2006, 211, T.Strafr. 2006, 25, with comment by F. Verbruggen. By introducing art. 32 PT CCP, the legislator explicitly wanted to codify the existing case law of the Court of Cassation. (Parl. St., Kamer, B.Z. 2010, DOC 53-0041/001, p. 3 and Parl. St., Kamer, 2012-2013, DOC 53-0041/002, pp. 2-3).

42 E. Maes, "Onrechtmatig verkregen bewijs en het integriteitsprincipe in het voorstel voor een nieuw Strafwetboek”, NC 2020, 499. 
procedural errors and a perception - not really backed up by empirical examples - that many guilty persons would profit from the strict rules on procedural errors while their interests have not really been harmed. ${ }^{43}$ Neither the judiciary, nor the legislative body ever really addressed the issue that poorly drafted and incoherent legislation on procedural rules may be a cause of law enforcement authorities' errors. Commentators pointed out that this remarkable leniency towards sloppy law enforcement and the judiciary stands in contrast to the increasingly strict application of procedural rules with regards to suspects and defendants, e.g. with regards to procedural deadlines and formalities. ${ }^{44}$

\section{Statutory Nullity}

The CCP hardly ever provides nullity as a sanction for failing to meet a procedural formality (infra). There always has been much case law on the 'exclusionary/admissibility rule' and the legislation concerning procedures for intrusive investigative measures has become ever more detailed and extensive. That makes it all the more striking how little legislative attention has been paid to the appropriate sanction for illegally obtained evidence. To a certain extent this can be explained by the fact that, originally, the code's drafters assumed that including procedural formalities in statute law was sufficient to guarantee the respect thereof. It appeared self-evident that what happened outside of the bounds of the law, would be inadmissible in subsequent criminal proceedings. ${ }^{45}$ This is why the CCP did not contain the initial 'exclusionary rule' and furthermore seldom explicitly provides nullity as a sanction for failing to meet a procedural formality. ${ }^{46}$ Nullity sanctions were included to stress that a certain requirement was important

43 Parl. St., Kamer, B.Z. 2010, DOC 53-0041/001, p. 3.

44 F. Verbruggen, "Voorwoord (Preface)" in J. Huysmans, 'Legitieme verdediging' (Legitimate defence), Antwerp, Intersentia, 2017, v.

45 B. De Smet, "Stromingen in het stelsel van nietigheden. Nieuwe criteria voor de uitsluiting van onrechtmatig verkregen bewijs", T.Strafr. 2005, (248) 249, who refers to F. Hélie, Traité de l'instruction criminelle, Brussels, Bruylant, 1863, III, 766.

46 S. De Decker, F. Verbruggen, "Across the River and Into the Poisonous Trees. From exclusion to the Use of Illegally Gathered Evidence in Criminal 
even though it could at first sight appear to be rather trivial. ${ }^{47}$ Since the U-turn in the case law in 2003, Parliament has included only few nullity sanctions in the CCP (infra), because nullity leaves absolutely no margin for appreciation for the judge. Lawmakers seem unwilling to take a stance and prefer to leave it to the judges to balance the interests at stake. For the same reason, one of the few nullity sanctions which was provided by law (in relation to the wiretap, which was introduced in 1993 with quite some reluctance and distrust towards law enforcement at the time) has been abolished in 2016. ${ }^{48}$ Parliament indeed considered that the consequences of the nullity sanction were too dramatic and disproportionate in the serious cases for which wiretaps are used. ${ }^{49}$

It should be noted, however, that case law did develop a category of so-called "substantial formalities". Although not accompanied by a statutory nullity sanction, judges considered those formalities nevertheless to be essential. Would a violation of said formalities lead to exclusion of evidence? Following a Court of Cassation decision of 16 November 2004 , it did not seem to be relevant whether a formality was considered substantial or not. The consequences of a violation of said formality had to be assessed in the same manner..$^{50}$ This therefore seemed to make the distinction between substantial and non-substantial formalities practically irrelevant. However, in 2013 the Court of Cassation did accept that a breach of a specific category of substantial formalities should lead to the exclusion of evidence: those relating to the organisation of courts

Proceedings in Belgium", in The XIIIth World Congress of Procedural Law: the Belgian and Dutch Reports, Antwerpen, Intersentia, 2008, 66.

47 Report on behalf of the committee, Parl.St. Kamer 2012-13, n. 53K0041/003, 60; C. Conings, Klassiek en digitaal speuren naar strafrechtelijk bewijs, Antwerp, Intersentia, 2017, 374-375.

Art. 66 of the Statute of 5 February 2016 amending criminal law and criminal procedure and laying down various provisions on justice, Official Bulletin 19 February 2016.

49 Explanatory Memorandum, Parl.St. Kamer 2015-16, nr. 54K1418/001, 62.

50 Court of Cassation decision of 16 November 2004, AR P.04.0644.N., RABG 2005, 504, RW 2005-06, 387, with comment by P. Populier, T.Strafr. 2005, 285, with comment by R.Verstraeten and S. De Decker, Vigiles (N) 2004 (excerpt), 171, with comment by F. Schuermans, confirmed in Court of Cassation decision of 15 November 2005, AR P.05.1275.N. 
and tribunals. ${ }^{51}$ The case concerned a home search which was mandated by a judge who did not have the power to authorise those searches. ${ }^{52}$ Though it seemed like an important correction, this case law was explicitly abandoned when Parliament introduced art. 32 PT CCP. ${ }^{53}$ Later case law confirmed that even in case of a breach of substantial formalities relating to the organisation of courts and tribunals, no exception applies. ${ }^{54}$

Whether judges consider a procedural safeguard to be substantial or not, has therefore become irrelevant. Only the violation of legal requirements explicitly accompanied by a statutory nullity sanction will automatically lead to exclusion of the evidence obtained. The sanction of nullity is currently only linked to some specific requirements for the seizure of real estate (art. 35bis CCP), testimony by a witness granted full

51 Court of Cassation decision of 24 April 2013, AR P.12.1919.F, ECLI:BE:CASS:2013:CONC.20130424.3, JT 2013, n. 6524, 416, concl. D. Vandermeersch, with comment by L.Kennes, RABG 2013, n. 14, 1013, concl. . D. Vandermeersch, with comment by V. Vereecke, T. Strafr. 2013, n. 6, 382, with comment. As implicitly introduced in Court of Cassation decision of 26 January 2013, AR P.10.1321.F, ECLI:BE:CASS:2011:ARR.20110126.4, RDPC 2012, n. 1, 82, with comment by D. Dillenbourg, T. Strafr. 2011, n. 4, 268, with comment by F. Schuermans.

52 See as well: C Conings, Klassiek en digitaal speuren naar strafrechtelijk bewijs, Antwerp, Intersentia, 2017, 26 and 370.

53 Report on behalf of the committee, Parl.St. Kamer 2012-13, n. 53K0041/010, 4-6; Report on behalf of the committee, Parl.St. Kamer 2012-13, n. 53K0041/015, 3-4. See as well: M.A. Beernaert "Les princesses de l'hôtel Conrad et la loi Antigone" (comment to Court of Cassation decision of 23 September 2015), JLMB 2016, n. 16, (762) 763; C. Conings, Klassiek en digitaal speuren naar strafrechtelijk bewijs, Antwerp, Intersentia, 2017, 372.

54 Court of Cassation decision of 10 June 2014, AR P.14.0282.N, ECLI:BE:CASS:2014:ARR.20140610.4, NC 2015, 196, with comment by B. Verstraeten, P. Vermoote, T.Strafr. 2015, n. 4-5, 227, with comment by L.Delbrouck, K. Truyen; Court of Cassation decision of 23 September 2015, AR P.14.0238.F, ECLI:BE:CASS:2015:CONC.20150923.4, RDPC 2016, n. 1, 72. See as well: M.A. Beernaert, "Les princesses de l'hôtel Conrad et la loi Antigone" (comment to Court of Cassation decision of 23 September 2015), JLMB 2016, n. 16, 762-764); L.Delbrouck, K. Truyen, "Artikel 32 V.T.Sv.: meer dan een loutere facelift" (comment to Cass. 10 June 2014), T.Strafr. 2015, n. 4-5, (228) 229-230; P. Vanwalleghem, "Antigoon geldt ook voor wettelijk geregeld bewijs”, De Juristenkrant 2014, n. 292, (7) 7. B. Verstraeten, P. Vermoote, "De onderzoeksrechter buiten saisine: een (proactieve) cowboy?" (comment to Court of Cassation decision of 10 June 2014), NC 2015, (197) 203. 
anonymity (art. 86bis and 86ter CCP) and when performing a polygraph test as of 1 January 2021 (new version of art. 112duodecies CCP which should take effect on said date).

Furthermore, statute law provides for an explicit sanction when statements are made during questioning which infringes the rules on questioning in violation of the right to legal assistance. Art. 47bis in fine CCP stipulates that no person can be convicted based on statements he made in breach of the right to and rules on prior confidential consultations and the assistance of a lawyer during questioning. This is, however, not strict nullity: such statements can for instance be used to convict third persons.

\section{UNRELIABILITY OF EVIDENCE BECAUSE OF THE ILLEGALITY}

As a second rule, judges must exclude illegally obtained evidence when the irregularity taints its reliability. Of course, judges always take reliability into account, also when assessing the probative value of legally obtained evidence. However, when the judge assesses the probative value of legally obtained evidence, unreliable evidence will not be 'excluded' in the strict sense of the word, i.e. it will not be declared inadmissible. Rather, the judge will simply decide not to rely on said evidence in deciding upon the defendant's guilt.

A prime example of evidence that may be unreliable as a result of the way in which it was gathered, is evidence that is dependent on the free will of the person providing it, notably witness statements and confessions. The reliability could clearly be tainted by illicit pressure or influence from the police. ${ }^{55}$ However, also other types of evidence can be unreliable due to irregularities. DNA tests for instance are regulated in detail. ${ }^{56} \mathrm{~A}$ violation of these rather technical regulations may just as well affect the reliability of the test results. ${ }^{57}$

55 S. De Decker, F. Verbruggen, “Across the River and Into the Poisonous Trees. From exclusion to the Use of Illegally Gathered Evidence in Criminal Proceedings in Belgium", in The XIIIth World Congress of Procedural Law: the Belgian and Dutch Reports, Antwerpen, Intersentia, 2008, 76-77.

56 Royal Decree 4 February 2002, Official Bulletin 30 March 2002.

57 S. De Decker, F. Verbruggen, "Across the River and Into the Poisonous Trees. From exclusion to the Use of Illegally Gathered Evidence in Criminal 


\section{VIOLATION OF THE RIGHT TO A FAIR TRIAL}

The third ground for exclusion is the most important one in practice. The Court of Cassation has set out a number of criteria to determine whether evidence obtained in an irregular manner must be excluded to ensure the right to a fair trial..$^{58}$ It confirmed these criteria after the introduction of art. 32 PT CCP. ${ }^{59}$ In the assessment, the judge may in particular take into account:

- the intentional or inexcusable nature of the rule-breaking by the investigators, ${ }^{60}$

- the seriousness of the irregularity in comparison to the seriousness of the offence under investigation, ${ }^{61}$

Proceedings in Belgium", in The XIIIth World Congress of Procedural Law: the Belgian and Dutch Reports, Antwerpen, Intersentia, 2008, 76-77.

58 Court of Cassation decision of 23 March 2004, AR P.04.0012.N, RABG 2004, 1061, with comment by F. Schuermans; Court of Cassation decision of 12 October 2005, AR P.05.0119.F., JT 2006, 109, JLMB 2006, 585, Pas. 2005, 1904, Rev.dr.pén. 2006, 211, T.Strafr. 2006, 25, with comment by F. Verbruggen; Court of Cassation decision of 31 October 2006, AR P.06.1016.N, T.Strafr. 2007, n. 1, 53, with comment by F. Schuermans and comment by J. Van Gaever; Court of Cassation decision of 23 September 2008, AR P.08.0519.N, T.Strafr. 2009, n. 3, 151, noot F. Schuermans; Court of Cassation decision of 5 June 2012, AR P.11.2100.N, ECLI:BE:CASS:2012:ARR.20120605.5, NC 2013, 439, with comment; Court of Cassation decision of 28 May 2013, AR P.13.0066.N, ECLI:BE:CASS:2013:CONC.20130528.9, RABG 2014, n. 1, 29, with comment by V. Vereecke, $R W$ 2013-14, n. 41, 1616, with comment by B. De Smet

59 Court of Cassation decision of 5 January 2016, AR P.15.1103.N, ECLI:BE:CASS:2016:ARR.20160105.7, RW 2015-16, 1.

60 Beernaert writes that the question whether the violation of the rules happened intentionally or not, might be relevant when deciding on disciplinary sanctions for those who broke the rules, but should not be decisive to determine what should happen to illegally gathered evidence. (M. Beernaert, "La preuve en matière pénale: principes généraux", in: Droit pénal et procédure pénale, Bruges, La Charte, looseleaf, (1) 20, n.43.) Maes convincingly responds that, to the extent that the exclusionary rule aims at underpinning the integrity of the criminal justice system, it does matter: intentional misbehaviour does justify a stronger reaction from the judge. (E. Maes, "Onrechtmatig verkregen bewijs en het integriteitsprincipe in het voorstel voor een nieuw Strafwetboek", NC 2020, 496).

61 Court of Cassation decision of 12 June 2019, n.. P.18.1001.F, Rev. dr. pén. entr., 2019, 289, ECLI:BE:CASS:2019:ARR.20190612.1: the rights of the 
- the fact that the illegally obtained evidence only relates to a material element of the existence of the offence, and not to the involvement of a specific person in committing the offence,

- that fact that the irregularity is of a purely formal nature,

- the impact of the irregularity on the freedom or right that the violated norm is intended to protect.

This list is not exhaustive. The Court of Cassation also refers to the respect police forces had for the loyalty principle enshrined in the CCP as a factor that judges can take into consideration in the exercise of their discretion. ${ }^{62}$ On several occasions, it has also taken into account circumstances which cast doubt on the reliability of the evidence obtained because of concerns as to the impartiality of the person who conducted the investigation. ${ }^{63}$ This consideration differs from the second ground for exclusion because it need not be established that the reliability of the evidence has indeed been tainted. The fact that circumstances cast serious doubt on the reliability of the evidence suffices to conclude that its use would lead to a breach of the right to a fair trial.

The criteria are indicative, they are not binding, nor is any single one of them decisive. For instance, the fact that law enforcement agencies committed the irregularity intentionally does not necessarily

defence can be balanced with the interest of society when assessing whether the trial is fair: Court of Cassation decision of 30 April 2014, n. P.13.1869.F. ECLI:BE:CASS:2014:ARR.20140430.2.

Court of Cassation decision of 5 November 2014, AR P.14.1170.F, ECLI:BE:CASS:2014:ARR.20141105.4 . CASS:2016:ARR.20161025.5; Court of Cassation decision of 12 June 2019, AR P.18.1001.F, ECLI:BE:CASS:2019:ARR.20190612.1. See in the same sense: ECtHR 19 February 2019, n. 25253/08, Ruşen Bayar/Turkey: "The Court reiterates that in determining whether the proceedings as a whole were fair, regard must be had to whether the rights of the defence have been respected, in particular whether the applicant was given the opportunity of challenging the admissibility and authenticity of the evidence and of opposing its use (see Panovits v. Cyprus, no. 4268/04, \& 82, 11 December 2008). In addition, the quality of the evidence must be taken into consideration, including whether the circumstances in which it was obtained cast doubt on its reliability or accuracy." 
lead to exclusion of the resulting evidence. ${ }^{64}$ The judge should take into account all the elements of the case to decide whether the use of the illegally obtained evidence would be contrary to the right to a fair trial. As a general rule, the judge is, however, not obliged to include all of the abovementioned criteria in the assessment and is free to use other criteria. ${ }^{65}$ In a 2018 decision, the Court of Cassation seemed to imply that in the assessment the judge must include the criteria that the parties to the proceedings have raised. ${ }^{66}$ In the same sense, the European Court of Human Rights has ruled that the right to a fair trial presupposes effective judicial control. The suspect must therefore be given the opportunity to challenge the admissibility and authenticity of the evidence. However, this possibility should not be purely theoretical and illusory. The judge must take a concrete position on the arguments raised and provide an appropriate response to the crucial points raised. ${ }^{67}$

${ }^{64}$ Court of Cassation decision of 31 October 2006, AR P.06.1016.N, T.Strafr. 2007 , n. 1, 53, with comment by F. Schuermans and comment by J. Van Gaever.

65 See by way of example: Court of Cassation decision of 31 October 2006, AR P.06.1016.N, T.Strafr. 2007, n. 1, 53, with comment by F. Schuermans and comment by J. Van Gaever.; Court of Cassation decision of 5 June 2012, AR P.11.2100.N, ECLI:BE:CASS:2012:ARR.20120605.5, NC 2013, 439, with comment; Court of Cassation decision of 28 May 2013, AR P.13.0066.N, ECLI:BE:CASS:2013:CONC.20130528.9, RABG 2014, n. 1, 29, with comment by V. Vereecke, $R W$ 2013-14, n. 41, 1616, with comment by B. De Smet; C. Conings, Klassiek en digitaal speuren naar strafrechtelijk bewijs, Antwerp, Intersentia, 2017, 367-368; T. Decaigny, "Bever, beroepsgeheim en bewijs" (comment to Court of Cassation decision 9 May 2007), T.Strafr. 2008, n. 2, (98) 100; B. De Smet, "Criteria en subcriteria voor de beoordeling van onregelmatigheden inzake de bewijsverkrijging" (comment to Court of Cassation decision 28 May 2013), RW 2013-14, (1620) 1624; P.Vanwalleghem, "Antigoon redt Kelkbewijs niet", Juristenkrant 2013, n. 272, 1 and 7; R.Verstraeten, S. De Decker, "Antigoon sluit de achterpoort, maar opent een raam" (comment to Court of Cassation decision 16 November 2004), T.Strafr. 2005, n. 6, (289) 290.

${ }^{66}$ A contrario reasoning based on the Court of Cassation decision 9 January 2018, AR P.17.0411.N, ECLI:BE:CASS:2018:ARR.20180109.3, VAV 2018, n. 2, 12, with comment by L. Brewaeys: "It follows that, in the absence of a written submission to that effect, the court is not required, when assessing whether the use of evidence is contrary to the right to a fair trial, to consider all those criteria."

67 ECtHR. 19 February 2019, n. 25253/08, Ruşen Bayar/Turkey. 
Whereas the broad, non-decisive and non-exhaustive criteria seem to leave a wide judicial discretion when assessing whether the right to a fair trial is breached, in practice it is mainly used to deny there is such a breach. ${ }^{68}$ Evidence is almost never excluded in court nowadays. ${ }^{69}$

\section{FRUITS OF THE POISONOUS TREE}

The Court of Cassation has always stood by the "fruit of the poisonous tree doctrine": if the conditions for exclusion are fulfilled, this entails not only that the original illegally obtained evidence but also its fruits must be excluded. ${ }^{70}$ If the original illegal action is covered by any of the three grounds for compulsory exclusion, judges cannot take into consideration "neither directly nor indirectly" any evidence found as a consequence of the original error. Nonetheless, both national judges ${ }^{71}$ and

68 Critical about this practice and the absence of a fundamental debate on the 'balancing act' of courts: L. Kennes, “L'impertinente Antigone ou le défaut de pertinence du critère d'équité pour décider de l'exclusion d'une preuve irrégulière”, Journal des Tribunaux, 2018, 2-9 and F. Kuty, "La nullité d'un élément de preuve pour contravention au caractère équitable de la procédure. L'essoufflement de l'article 6 de la Convention de sauvegarde des droits de l'homme et des libertés fondamentales", Liber amicorum Patrick Henry, Bruxelles, Larcier, 2019, 15-43.

69 The Antigoon doctrine which had its origin in criminal procedure, even made its way into other branches of law: J. Van Doninck, Het lot van onrechtmatig bewijs (The faith of illegal evidence), Antwerp, Intersentia, 2020, xvi + 380 p. Some lower labour law courts are resisting pressure from the Court of Cassation to extend the Antigoon-case law to social law matters (conflicts between employers and workers, dismissal cases): see on illegal GPS-monitoring of workers, which was excluded by the lower court: K. Rosier, "Illégalité d'un système de traçage G.P.S. et preuve irrégulière”, JLMB 2020, 1353-1356.

70 Court of Cassation decision of 16 June 1987, Arr. Cass. 1986-87, nr 627; Court of Cassation decision of 22 May 2001, T. Strafr. 2002, 36; Court of Cassation decision of 30 March 2010, T. Strafr. 2010, 276, with comment by K.Beirnaert K. Beirnaert.

71 Court of Cassation decision of 15 January 2019, n. P.18.0790.N, ECLI:BE:CASS:2019:ARR.20190115.3, Pasicrisie Belge 2019, 84-87: a final decision by a court had found that a search was illegal. Defendants alleged that the wiretap in their separate case had been based on this illegal initial search and should be considered illegal, too. In vain: the courts decided that there had been enough other elements to justify the wiretap warrant and refused to declare it null and void. 
the European Court of Human Rights ${ }^{72}$ have accepted that 'other evidence' was unrelated to the illegally gathered evidence, that metaphorically it was 'fruit of a different tree' and that the unrelated evidence was sufficient to found a conviction. The decisions on pre-trial preventive detention also seem to be 'a different tree': the Court of Cassation stresses that illegally gathered information can $^{73}$ and often even should ${ }^{74}$ be used by judges deciding on the arrest or the continued detention on remand of suspects.

\section{Which JUdGE CAN OR MUST EXCLUDE THE ILLEGAL EVIDENCE?}

Under the existing CCP, which provides for two types of criminal investigation (preliminary investigation and judicial inquiry), the moment in the procedure at which the evidence will be excluded may differ. At the end of the judicial inquiry, the so-called pre-trial chambers (like the Chamber of Indictment of the Court of Appeals) should eliminate the illegally gathered evidence (art. 235bis CCP). The idea was to avoid that the trial judge would still be psychologically influenced by the evidence he is supposed to ignore. However, if the issue has not been raised in the pre-trial stage, it will still be possible to raise it at the actual trial. Furthermore, the Court of Cassation has suggested that exclusion of illegally obtained evidence by the pre-trial chambers is only possible in case of nullity or violation of the right to a fair trial. The second ground, unreliability caused by the irregularity of the gathering, cannot be judged

72 E.g. ECtHR (Grand Chamber) 1 June 2010, n. 22978, Gäfgen/Germany.

73 The mere fact that an irregularity has been committed at the opening of the inquiry does not necessarily mean that it has emptied the rights of defense of the accused of their very substance. It does not follow from any legal or treaty provision that serious indications of guilt gathered during an irregular search must necessarily be excluded by the judge in charge of the control on the preventive detention, nor that this judge cannot decide to take them into consideration. (Court of Cassation decision of 29 May 2019, n. P.19.0546.F, ECLI:BE:CASS:2019:ARR.20190529.4).

74 The fact that the user of a call number has been identified in violation of Article 46bis CCP does not authorise the pre-trial chambers, ruling on preventive detention, to disregard this information, except in the three cases where Article 32 PT CCP provides for such a sanction. (Court of Cassation decision of 6 February 2019, n. P.19.0097.F, ECLI:BE:CASS:2019:ARR.20190206.3) 
by the pre-trial chambers, as it requires an assessment of the probative value of the evidence and this is not their task. It should be left to the trial judge.${ }^{75}$ Regardless, the overwhelming majority of investigations are preliminary investigations conducted by the public prosecutor, which are not subject to the supervision of the pre-trial chambers, so any decision on exclusion or admission of illegally gathered evidence will be taken by the trial court. There is an important exception, though: if so-called special investigative methods have been used (undercover agents, secret visual surveillance, but not wiretap or covert search in IT-systems) the pre-trial Indictment Chamber will perform a control of legality even after a preliminary investigation (art. 235ter CCP). The pre-trial proceedings are not open to the public and the procedure is organised in such a way as to allow judicial control without revealing too much about the methods and technical means used or the identity of the people involved in the covert police operations.

\section{No EXCLUSION OF EXCULPATORY EVIDENCE ${ }^{76}$}

In one situation illegally gathered evidence is always admissible: if the evidence is exculpatory, suspects can always rely on it. ${ }^{77}$ It does not matter whether suspects or defendants were personally involved in the illegal actions or not. ${ }^{78}$ For instance, when a witness statement containing some exculpatory information is illegal (e.g. violation of the public nature of the court sessions), the suspect can use the information in his defence

75 Court of Cassation decision of 3 April 2012, Pasicrisie 2012, 745; Court of Cassation decision of 19 May 2015, AR P.14.0921.N, T. Strafr. 2015, 261; in Court of Cassation decision of 4 April 2017, n. P.16.0351.N. it clarified that even if the pre-trial judge found the reliability was no problem, parties can still raise this issue before the trial judge, who is free to decide on the matter.

76 S. De Decker, F. Verbruggen, "Across the River and Into the Poisonous Trees. From exclusion to the Use of Illegally Gathered Evidence in Criminal Proceedings in Belgium", in The XIIIth World Congress of Procedural Law: the Belgian and Dutch Reports, Antwerpen, Intersentia, 2008, 72-73.

Court of Cassation decision of 12 November 1997, Rev.dr.pén. 1998, 586.

R.Verstraeten, Handboek strafvordering (Companion to criminal procedure), Antwerp, Maklu, 2007, no. 1739, 870. 
all the same. ${ }^{79}$ As it happens, evidence which is exculpatory for one of the suspects can indeed be quite damaging for another suspect. Judges will have to consider it in favour of the former, but ignore it when dealing with the latter. That is easier said than done.

\section{No Help From Above: Acquiescence From The European COURTS}

The Court of Cassation took the initiative to admit illegally gathered evidence routinely and exclude it only rarely. The new rule was subsequently written into the CCP by the Belgian Parliament and unsuccessfully challenged before the Belgian Constitutional Court. Hence, opponents who hoped to reverse or mitigate the current rule, could only attempt to challenge it at the European level. However, the European Court of Human Rights in Strasbourg has always been reluctant to meddle with member state rules on evidence. It has held that - at least for very serious offences and if the defendant had been given enough opportunity to challenge it - the Belgian practice did not violate the ECHR. ${ }^{80}$

A new front was opened, when in 2015 the European Union's Court of Justice in Luxembourg (hereinafter: CJEU) surprised everyone by stating in its WebMindLicenses Kft-judgement that if rules of EU law, including the EU Charter of Fundamental Rights, have been violated in the collection of evidence, the principle of effectiveness of Union law requires that member state judges exclude the evidence. ${ }^{81}$ This prompted the Belgian Constitutional Court to ask for clarification in a preliminary question': if the CJEU found that Belgian rules on the compulsory retention of metadata by telecom and internet service providers for subsequent access and use by law enforcement (ICT traffic and location data) violated

79 Court of Cassation decision of 3 November 1999, T.Strafr. 2000, 255, with comment by J. Meese.

80 First the Antigoon case law (ECtHR 28 July 2009, n. 18704, Lee Davies/ Belgium.), subsequently art.32 PT CCP (ECtHR 31 January 2017, n. 40233/07, Kalneniene/Belgium, T.Strafr. 2017, 112, with comment by C. Van De Heyning.)

81 European Court of Justice 17 December 2015, Case C-419/14, ECLI:EU:C: 2015:832, §§ 68 and 86-89. 
the EU Charter of Fundamental Rights, did that create an obligation for Belgian judges to exclude all evidence resulting from such access and use of the data? ${ }^{82}$ Could at least past cases be saved in which it had been assumed - wrongly, as it turned out - that the practice was not illegal under EU law?

In its somewhat sibylline judgement of 6 October 2020, the CJEU adopted a strict approach regarding the (il)legality, but a mild one regarding the use of illegal evidence. ${ }^{83}$ Under the principle of primacy of EU law over national law, the CJEU claims the exclusive right to set temporary limits on the effect of any illegality, "in exceptional cases, on the basis of overriding considerations of legal certainty, allow the temporary suspension of the ousting effect of a rule of EU law with respect to national law that is contrary thereto". ${ }^{44}$ National (constitutional) courts are not entitled to set temporal limits on a declaration of illegality and in this case the CJEU itself refused to do it. The Court was more flexible, however, with respect to the subsequent "use in criminal proceedings, of information and evidence obtained as a result of the general and indiscriminate retention of traffic and location data" in breach of EU law. According to the CJEU, as EU law currently stands, "it is for member state national law alone to determine the rules relating to the admissibility and assessment, in criminal proceedings against persons suspected of having committed serious criminal offences, of information and evidence obtained by such retention of data contrary to EU law". ${ }^{55}$ It is remarkable that the CJEU only seems to refer to said national autonomy in relation to proceedings concerning 'serious criminal offences'. The Court therefor still leaves the question open whether a breach of EU

82 Constitutional Court 19 July 2018, n. 96/2018; Cfr. F.Verbruggen, S.Royer, H. Severijns, "Reconsidering the blanket-data-retention-taboo, for human rights' sake? Belgian Constitutional Court offers CJEU chance to explain its puzzling Tele2 Sverige AB-decision”, EULawblog 1 October 2018: https://europeanlawblog.eu/2018/10/01/reconsidering-the-blanket-data-retention-taboo-for-human-rights-sake/

83 European Court of Justice (Grand Chamber) 6 October 2020, Joined Cases C-511/18, C-512/18 and C-520/18, ECLI:EU:C:2020:791. C-511/18, C-512/18 and C-520/18, ECLI:EU:C:2020:791, § 216. 
law in relation to a less serious offence should indeed lead to exclusion of the illegally obtained evidence further to the principle of effectiveness of EU law. The CJEU furthermore stresses that the EU law principle of effectiveness, may be achieved "not only by prohibiting the use of such information and evidence, but also by means of national rules and practices governing the assessment and weighing of such material, or by factoring in whether that material is unlawful when determining the sentence." ${ }^{86}$ However, the CJEU omits to clarify under what circumstances the illegality should at least affect the weight of the evidence or sentence to be imposed. For Belgium, article 32 PT CCP denies the trial judges the right to exclude the evidence, but is silent about taking the illegality into account in weighing the evidence or at sentencing. The CJEU warns that the evidence should nevertheless be excluded from criminal proceedings if the suspects "are not in a position to comment effectively on that information and that evidence and they pertain to a field of which the judges have no knowledge and are likely to have a preponderant influence on the findings of fact." ${ }^{87}$ This does not seem to differ from the existing Belgian exclusionary rule if the right to a fair trial would be affected.

\section{Vi. Alternative Ways To Sanction Investigative Misbehaviour}

In extreme cases of investigative misbehaviour, judges can opt for the ultimate procedural sanction: the inadmissibility of the criminal proceedings as a whole. ${ }^{88}$ In Belgium this 'sledge hammer' is rarely used ${ }^{89}$,

86 European Court of Justice (Grand Chamber) 6 October 2020, Joined Cases C-511/18, C-512/18 and C-520/18, ECLI:EU:C:2020:791, § 225. European Court of Justice (Grand Chamber) 6 October 2020, Joined Cases C-511/18, C-512/18 and C-520/18, ECLI:EU:C:2020:791, §§ 226-227. Court of Cassation decision of 12 June 2019, P.18.1001.F.

Court of Cassation decision of 10 February 2016, P.15.1505.F, ECLI:BE:CASS:2016:ARR.20160210.5, Rev. dr. pén. 2016, 841; Court of Cassation decision of 12 June 2019, P.18.1001.F, ECLI:BE:CASS:2019:ARR.20190612.1. The Court of Cassation has made it very difficult for trial courts to use this sanction. It stated that "as a rule, the sanction for the irregularity of evidence does not consist in the inadmissibility of the public action, but in the obligation for the judge to set aside the irregular elements and then to base his decision only on the other elements of evidence that may exist, insofar as they have been obtained in 
mainly in cases of extreme bad faith of the investigators ${ }^{90}$ and of police provocation (entrapment). Offences are provoked if the intention to commit the offence was generated or reinforced - or endorsed when the suspect no longer wanted to commit the offence - by a police officer or a third person acting at the request of the police..$^{91}$ The Court of Cassation stressed that judges cannot base the inadmissibility on "the sole circumstance that a rule relating to the administration of proof, the disregard of which is sanctioned criminally, has not been complied with; it

a regular manner without simply stemming from the irregular elements or being inseparably linked to them; on the other hand, the judge may only declare the public action inadmissible if it is established that, despite having set aside the irregular evidence, it remains absolutely impossible for the court to decide on the admissibility of the public action with respect for the right to a fair trial guaranteed by Article 6 ECHR.” (F. Kuty, N. Colette-Basecqz, E. Delhaise, O. Nederlandt, H.D. Bosly, L. Kennes, D. Vandermeersch, "Chronique semestrielle de jurisprudence 2020/1”, Revue de Droit Pénal et de Criminologie, 2020, 582, referring to Court of Cassation decision of 20 November 2018, AR P.18.0688.N, ECLI:BE:CASS:2018:ARR.20181120.5, Rechtskundig Weekblad 2018-2019, 1661.See also: L. Kennes, and D. Holzapfel, "La déloyauté d'un enquêteur peut justifier l'écartement des procès-verbaux rédigés par celui-ci sans pour autant impliquer l'irrecevabilité des poursuites", JLMB 2020, 1468-1477.

Inadmissibility should be used when the investigation has been disloyal from the outset, the rights of defence of the suspect repeatedly violated seriously and definitively and the defendants have been irremediably deprived of their right to a fair trial. (Court of Appeals Brussels 10 December $2010, J T 2011,54$.) It would also be pronounced if the judicial inquiry has been completely coloured by the partiality of the investigating judge. Cfr.: Court of Cassation decision of 31 May 2011, AR P.10.2037.F, ECLI:BE:CASS:2011:ARR.20110531.1, JT 2011, 583, opinion J. Genicot, with comment by M.A. Beernaert, JLMB 2011, 1524, with comment by A. De Nauw; cfr also K. Beirnaert, "Het recht van verdediging en de onmogelijkheid de regelmatigheid van de procedure te controleren: staat de ontvankelijkheid van de strafvordering niet op het spel?" (comment on Court of Cassation decision of 30 March 2010), T.Strafr. 2010, 277-281. Y. Liègeois and B. De Smet, "Twintig jaar zuivering van nietigheden tijdens het gerechtelijk onderzoek. Tijd voor verandering of opfrissing van het systeem", RW 2019-20, 8 point out: "In some cases it is impossible to filter the illegally obtained elements from the evidence and to continue the procedure without them. Then the judge must declare the prosecution inadmissible if the first link of the procedural chain is compromised. If an offense is detected by the use of techniques which are incompatible with the law or general principles of law, there is no evidence for the judge to use." 
is not otherwise when the irregular proof constitutes the sole or determining basis for the identification of the offender." 92

Furthermore, the person who gathered the evidence may be criminally liable. This depends on the nature of the illegal action. If the conduct is punishable by law (e.g. conducting a search or a wiretap without a warrant is a criminal offence), this person can be prosecuted. Sometimes the identity of persons is protected by law (informers and undercover agents: art. 47octies and art. 47 decies CCP). Although the public prosecution service can reveal their identity if crimes were committed, it cannot be forced to do so by judges, if it decides the identity should be protected. Belgium is probably unique in the world, in the sense that any public authority can incur criminal liability (article 5 Criminal Code). That includes the federal state: it could be held criminally liable for the behaviour of investigators, prosecutors or judges.

Persons who have been unfairly dealt with, can also hold the state liable under tort law for any loss that the illegal evidence gathering has caused them. They will have to demonstrate the causal relation between the illegal evidence and their material or moral loss before a civil court (art. 1382 Civil Code).

\section{Potential Use of Illegally Obtained Evidence in the Framework of Out of Court Settlements}

The prosecution can also propose to solve the case out of court, by way of financial settlement or mediation..$^{93}$ Since out of court settlements always require the suspect's consent, a suspect who believes that the prosecution service has based its case on illegal evidence which should be excluded, can refuse to accept. However, as most of the times illegal evidence can still be used, there is nothing that would prevent its use to convince a suspect to accept a settlement. Indeed, by making generous settlement offers to suspects, the prosecutors can avoid judicial scrutiny of rule breaking in the course of the preliminary investigation. Judges do

92 Court of Cassation decision of 23 January 2019, P.18.0623.F, ECLI:BE:CASS:2019:ARR.20190123.12 .

93 Articles 216bis and 216ter CCP. 
have to validate the settlement if a judicial inquiry has been initiated or if the case was already pending before the criminal court.

\section{FINAL REMARKS 94}

Privileging material truth-finding and punishment of perpetrators over the procedural protection of individual rights, Belgium has made it very difficult for judges to exclude illegally gathered evidence. ${ }^{95}$ That this system seems compatible with European (human rights) law, does not mean there is no room for improvement.

We do not advocate a return to the old strict exclusionary rule. There are good reasons to mitigate it, without the overcompensation of current Belgian law. The underlying rationale of the exclusion of illegally obtained evidence has always been and remains that this sanction will have a dissuasive effect on overzealous police officers, prosecutors and perhaps even investigating judges. In real life this type of sanction may not reduce the unwanted behaviour as much as it would stimulate creativity in searching ways to avoid the sanction, e.g. 'evidence laundering' by third parties. ${ }^{96}$ Moreover, the distance - both in terms of time and psychologically - between the illegal action and the potential exclusion of the evidence is considerable. Under Belgian criminal procedural law, the people behaving improperly during the investigation are rarely called to answer in person at the trial for their procedural misbehaviour. For unintentional, inadvertent breaking of the rules by investigators, one should not expect too much of a deterrent effect for exclusion as a

94 This is on update of the analysis from: D. De Decker, F. Verbruggen, "Across the River and into the Poisonous Trees. From Exclusion to Use of Illegally Gathered Evidence in Criminal Proceedings in Belgium", in The XIIIth World Congress of Procedural Law: the Belgian and Dutch Reports, Antwerp, Intersentia, 2008.

95 E. Cape, J. Hodgson, T. Prakken and T. Spronken, "Procedural rights at the investigative stage: towards a real commitment to minimal standards" in E. Cape, J. Hodgson, T. Prakken and T. Spronken (eds.), Suspects in Europe. Procedural rights at the investigative stage of criminal process in the European Union, Antwerp, Intersentia, 2007, (1) 14.

Supra III.1.From exclusion to admission. 
sanction. The biggest policy problem is that a consistent application of the exclusionary rule produces results which both practitioners and public opinion find hard to swallow. The exclusionary rule is mostly - or only - to the advantage of 'guilty' suspects. When a case does not entail criminal proceedings, innocent persons whose rights were violated, will not benefit from this sanction. In conclusion, the exclusion of reliable, but illegally gathered evidence does not always sanction or reward the right persons. Sometimes admitting the evidence does make sense. ${ }^{97}$

The current Belgian system lacks coherence. On the one hand it is legalistic to the extreme, in the sense that it links obligatory exclusion to the violation of a formality for which statutes explicitly provide nullity. This is rather peculiar, as everyone knows that in Belgian statutory law such provisions are very rare. One could say the Court of Cassation passed the buck to Parliament, which should provide nullity for every formality which it deems essential. So far, the suggestion has fallen on deaf ears. On the other hand the current rules turn on the criterion of the right to a fair trial as a kind of panacea. The Belgian standards - which used to be relatively high - are reduced to the absolute minimum level of Strasbourg case law. As such, violations of the right to privacy do not entail an infringement on the right to a fair trial. ${ }^{98}$ Belgium took Strasbourg case law, which should be an absolute minimum states should never fall below, and turned it into the only standard and consequently into the maximum level of protection. ${ }^{99}$

97 See F. Verbruggen, "Vindt het spook van Antigoon rust? Franstalig "schoonmoedersarrest" als slotluik van de nieuwe cassatierechtspraak over de uitsluiting van onrechtmatig bewijs" (French-language "mother-in-law decision" as the capstone for the exclusion of illegally obtained evidence. Comment on the Court of Cassation decision of 12 October 2005), T.Strafr. 2006, (26) 27-28.

98 ECtHR 12 May 2000, Khan / U.K.; ECtHR 25 September 2001, P.G. and J.H. / U.K.; ECtHR 5 November 2002, Allen / U.K.; ECtHR 9 December 2004, Van Rossem / Belgium. See for instance: Court of Cassation decision 19 April 2016, P.15.1639.N, ECLI:BE:CASS:2016:ARR.20160419.3.

99 F. Verbruggen, "Vindt het spook van Antigoon rust? Franstalig "schoonmoedersarrest" als slotluik van de nieuwe cassatierechtspraak over de uitsluiting van onrechtmatig bewijs" (French-language "mother-in-law decision" as the capstone for the exclusion of illegally obtained evidence. Comment on the Court of Cassation decision of 12 October 2005), T.Strafr. 2006, (26) 29-30. 
One can understand that the Belgian authorities are concerned that ever more detailed procedural rules in combination with more adversarial style defence tactics will lead to trials in which procedural discussions overshadow the merits and the substantive issues of criminal law. Is this a nostalgic longing for trials with debates centred more on the defendants and less on the investigators? Much as we appreciate this concern, we would like to warn against phobic traits in the judicial dislike of defence arguments related to procedural errors. Any pharmacologist knows that small doses of poison can sometimes be beneficial for an organism. Still, the Belgian criminal justice system's appetite for poisoned fruit can be dangerous, if not lethal, in the long run. It is unduly lenient for sloppy performance and even for mischievous practices by investigators.

Rather than the (individual or general) deterrence of investigators, it should be the overall image of the criminal justice as trustworthy and the exemplary 'proper, lawful' behaviour of those representing it, that should guide the legal regime for illegally gathered evidence. Like other authors, we have suggested that Parliament should make exclusion the rule again, but allow judges to use the evidence in a number of exceptional situations. ${ }^{100}$ Unlike now, investigators who infringe the rules should not be sure from the outset that their illegal actions will not affect the evidence and judges should explain why they do use evidence in spite of the fact that it was illegally gathered.

Now that Belgium is finally getting rid of the Napoleonic CCP and considering the adoption of a new one, Parliament should grasp the opportunity to redress matters. Whether the proposal for a new CCP will eventually be adopted, remains to be seen. ${ }^{101}$ In any event, its drafters

${ }^{100}$ C.Conings, Klassiek en digitaal speuren naar strafrechtelijk bewijs (Classical and digital searches for criminal evidence), Antwerp- Cambridge, Intersentia, 2017, 737 a.ff. and 760 .

${ }^{101}$ It involves abolition of the archaic, dysfunctional jury trial system, used only in 0,007 percent of cases, but politically a sacred cow. That common sense proposals are controversial in Belgium, is also apparent in the resistance against a single system of criminal investigation led by the prosecution service under judicial control. The judge-inquisitor would disappear: whether or not investigators would be allowed to infringe fundamental rights would be decided by judges who are not conducting the investigation themselves. The spokespeople of the union of investigating judges are now actively 
are intent on changing the rules on illegal evidence. ${ }^{102}$ Normality would be restored in the sense that legal rules must be followed and if they are not, as happens with illegally gathered evidence, the principle is that it should not be used à charge. ${ }^{103}$ The Drafting Committee is right in stressing that under the Rule of Law, a state cannot take as a norm that illegally gathered evidence should be used. Information gathered in violation of the rights of the defence, the right to privacy, the right to a private life, the integrity of persons, in violation of rules on the competence of judges and courts or in violation of the secrecy of journalistic sources, should be excluded, as well as information derived from it ('fruit of the poisonous tree' will be poisoned).

However, the drafters do not envisage a return to the old strict exclusionary rule: judges will be allowed to make exceptions. They should consider the seriousness of the violation, the legal interest at stake and other circumstances of the specific case to allow the use when

$1^{\circ}$ it is not the result of an intentional and unjustifiable violation of the protected legal interest,

$2^{\circ}$ the seriousness of the legal rule or interest that was affected in the specific case does not outweigh the interest of society in prosecuting the evidence and punishing the perpetrator and $3^{\circ}$ the use of the evidence is not detrimental to the integrity of the criminal justice system.

'campaigning' to keep the status quo with some minor changes. Belgian politicians, even though continuously talking about change and progress, tend to be very conservative in their approach of the country's dysfunctional criminal justice system.

${ }^{102}$ The draft is not yet public, as the Bill is being scrutinised by the Council of State. The main lines were already presented to Parliament at public hearing and written down by the Committee's co-ordinator, prof.dr. R. Verstraeten: Cfr. R.Verstraeten, A.Bailleux, “"Het voorstel van een nieuw Wetboek van strafvordering: algemene beginselen en fase van het onderzoek (The proposal for a new CCP: general principles and the investigation stage)”, in: Themis Straf-en strafprocesrecht, academiejaar 2018-19, Bruges, Die Keure 2019, 172-176. The text is said to have inspired a Bill proposed by individual Members of Parliament: https://www.dekamer.be/flwb/pdf/55/1239/55K1239001.pdf

103 The existing principle that it can be used by the defence, i.e: à décharge, would be made explicit in statute law. Supra III.7. 
In addition to this broad discretion to judge the appropriateness of excluding or using illegally gathered evidence, there are two instances in which judges have an absolute obligation to exclude. This would be more strict than the case law of the European Court of Human Rights ${ }^{104}$ : evidence which results from inhuman and degrading treatment must always be excluded. The other will prove even more controversial (and might be amended by Parliament): if the law required authorisation (a warrant) by a judge for an investigative action and such authorisation has not been obtained. Less serious violations could be the basis for exclusion if the judge feels they are detrimental to the integrity of the criminal justice authorities.

Since the integrity of the criminal justice system is at stake, not just the rights of the specific individual, exclusion is due regardless of whether the person requesting the exclusion was personally affected by the illegal action. If only the rights of someone who is not being prosecuted have been violated, for instance by an illegal search, the evidence can be excluded and the defendants could 'profit' from this.

The drafters reject the distinction made between 'police information' on the one and 'evidence' on the other hand, since they believe the two are often inextricably linked. It does distinguish, as

${ }^{104}$ Whereas the European Court of Human Right is unambiguous case for torture, on evidence produced by inhuman and degrading treatment, it depends on the bearing of the violation on the outcome. (ECtHR (Grand Chamber) 11 July 2006, n. 54810/00 Jalloh/Germany, § 105 (for torture), but in § 107: "the general question whether the use of evidence obtained by an act qualified as inhuman and degrading treatment automatically renders a trial unfair can be left open" because in the specific case (\$ 108) "the Court finds that the use in evidence of the drugs obtained by the forcible administration of emetics to the applicant rendered his trial as a whole unfair." Later (ECtHR (Grand Chamber) 1 June 2010, n. 22978/05, Gäfgen/Germany, § 178) it clarified: “Article 3 may therefore also require, as a rule, the exclusion from use at trial of real evidence which has been obtained as the result of any violation of Article 3, even though that evidence is more remote from the breach of Article 3 than evidence extracted immediately as a consequence of a violation of that Article. Otherwise, the trial as a whole is rendered unfair. However, the Court considers that both a criminal trial's fairness and the effective protection of the absolute prohibition under Article 3 in that context are only at stake if it has been shown that the breach of Article 3 had a bearing on the outcome of the proceedings against the defendant, that is, had an impact on his or her conviction or sentence." 
the Court of Cassation has always done, between the knowledge of the existence of offence (which is not affected by the illegality) and the actual use of illegal evidence. Only if the initial knowledge has its origin in torture, inhuman or degrading treatment, any prosecution would become impossible.

The new rules would have as a consequence that debates on how far the authorities can go will once again take place in open court, but not that serious criminals would be acquitted because of minor bureaucratic errors. Intentional wrongdoing will have more consequences than unintentional mistakes. The trial judge ${ }^{105}$, which will have heard all the interested parties, is best placed to balance the conflicting interests and decide what is best for society. ${ }^{106}$ Unlike now, the investigators will not know from the outset that whatever happens, the evidence will always be used. Such uncertainty can only be a stimulus to respect the law. That is what officers have sworn to do, anyway.

\section{Bibliographical REFERENCES}

M.A. BEERNAERT, "Les princesses de l'hôtel Conrad et la loi Antigone" (comment to Court of Cassation decision of 23 september 2015), JLMB 2016, 762-764; K. BEIRNAERT, "Het recht van verdediging en de onmogelijkheid de regelmatigheid van de procedure te controleren: staat de ontvankelijkheid van de strafvordering

${ }^{105}$ Exclusion at the pre-trial stage is no longer envisaged by the proposal.

${ }^{106}$ At this point we see things slightly differently from Maes, who, like many others, fears that a casuistic approach leads to legal uncertainty and unequal treatment. She thinks that either statute law or the Court of Cassation should develop more detailed rules (E.Maes, "Onrechtmatig verkregen bewijs en het integriteitsprincipe in het voorstel voor een nieuw Strafwetboek", NC 2020, 499 (and the authors mentioned in footnote 58) and 504). We think that exceptionally some legal uncertainty can be functional: the rule breaking law enforcement authority cannot rest assured that the illegal evidence can be used regardless, the defendant (who is not necessarily the victim of the rule breaking) has an incentive to raise the issue and provoke a debate on the integrity of the evidence gathering, but should not necessarily know in advance with absolute certainty that the evidence can never be used. 'No peace for the wicked' (at least not until the end of the trial), one could say. Or rather: 'less peace than under the current regime of article 32 PT CCP'. 
niet op het spel?" (comment on Court of Cassation decision of 30 March 2010), T.Strafr. 2010, 277-281;

E. CAPE, J. HODGSON, T. PRAKKEN and T. SPRONKEN, "Procedural rights at the investigative stage: towards a real commitment to minimal standards" in E. CAPE, J. HODGSON, T. PRAKKEN and T. SPRONKEN (eds.), Suspects in Europe. Procedural rights at the investigative stage of criminal process in the European Union, Antwerp, Intersentia, 2007, 1-29;

C. CONINGS, Klassiek en digitaal speuren naar strafrechtelijk bewijs, Antwerp, Intersentia, 2017, 862 p.;

T. DECAIGNY, "Bever, beroepsgeheim en bewijs" (comment to Court of Cassation decision 9 May 2007), T.Strafr. 2008, n. 2, 98-102;

T. DECAIGNY, Tegenspraak in het vooronderzoek, Antwerpen, Intersentia, 2013, 719 p.;

J. DE CODT, “Preuve pénale et nullités”, RDPC 2009, 634-666.

J. DE CODT, “La nouvelle loi sur les nullités: un texte inutile?”, RDPC 2014, 245-266.

S. DE DECKER, F. VERBRUGGEN, "Across the River and Into the Poisonous Trees. From exclusion to the Use of Illegally Gathered Evidence in Criminal Proceedings in Belgium”, in The XIIIth World Congress of Procedural Law: the Belgian and Dutch Reports, Antwerpen, Intersentia, 2008, 63-90;

L. DELBROUCK, K. TRUYEN, "Artikel 32 V.T.Sv.: meer dan een loutere facelift" (comment to Cass. 10 June 2014), T.Strafr. 2015, n. 4-5, 228-230;

B. DE SMET, "Criteria en subcriteria voor de beoordeling van onregelmatigheden inzake de bewijsverkrijging" (comment to Court of Cassation decision 28 May 2013), RW 2013-14, 1620-1624;

B. DE SMET, "Stromingen in het stelsel van nietigheden. Nieuwe criteria voor de uitsluiting van onrechtmatig verkregen bewijs”, T.Strafr. 2005, 248-266;

F. HÉLIE, Traité de l'instruction criminelle, Brussels, Bruylant, 1863, III, 766 ;

L. KENNES, "L'impertinente Antigone ou le défaut de pertinence du critère d'équité pour décider de l'exclusion d'une preuve irrégulière”, JT 2018, 2-9;

L. KENNES and D. HOLZAPFEL, "La déloyauté d'un enquêteur peut justifier l'écartement des procès-verbaux rédigés par celui-ci sans pour autant impliquer l'irrecevabilité des poursuites", JLMB 2020, 1468- 1477. 
J. KERKHOFS, P. VAN LINTHOUT, Cybercrime 3.0, Brussels, Politeia, 2019, 846 p.;

O. KLEES, "La preuve en droit pénal: une évolution de la jurisprudence ou 50 nuances d'Antigone?", note sous Cass., 18 janvier 2017, P.16.0626.F, R.D.P.C 2017, 640-655;

F. KUTY, "La nullité d'un élément de preuve pour contravention au caractère équitable de la procédure. L'essoufflement de l'article 6 de la Convention de sauvegarde des droits de l'homme et des libertés fondamentales", Liber amicorum Patrick Henry, Bruxelles, Larcier, 2019, 15-43.

F. KUTY, “La règle de l'exclusion de la preuve illégale ou irrégulière: de la précision au bouleversement. », note sous Cass. 14 octobre 2003, R.C.J.B., 2004, 408 à 438;

Y. LIEGEOIS, B. DE SMET, "Twintig jaar zuivering van nietigheden tijdens het gerechtelijk onderzoek. Tijd voor verandering of opfrissing van het systeem”, RW 2019-20, 3-19;

E. MAES, "Onrechtmatig verkregen bewijs en het integriteitsprincipe in het voorstel voor een nieuw Strafwetboek”, Nullum Crimen 2020, 493-504.

J. MONBALLYU, Zes eeuwen strafrecht, de geschiedenis van het Belgische strafrecht (1400-2000) (Six Centuries of Criminal Law, the History of Belgian Criminal Law (1400-2000)), Leuven, Acco, 2006, 384 p.;

F. SCHUERMANS, "Cassatie bevestigt bijzonder statuut politionele aanvangsinformatie”, Juristenkrant 2015, n. 306, 2;

F. SCHUERMANS, "De zoektocht naar of de jacht op de oorsprong van de politionele informatie als start van een strafrechtelijk vooronderzoek", T. Strafr. 2014, n.1, 47-53;

C. VAN DEN WYNGAERT, P. TRAEST, S. VANDROMME, Strafrecht en strafprocesrecht, Antwerpen, Maklu, 2017, 1406 p.

P. VANWALLEGHEM, “Antigoon geldt ook voor wettelijk geregeld bewijs”, De juristenkrant 2014, n. 292, 7;

P. VANWALLEGHEM, “Antigoon redt Kelkbewijs niet”, Juristenkrant 2013, n. 272, 1 and 7;

F. VERBRUGGEN, "Vindt het spook van Antigoon rust? Franstalig "schoonmoedersarrest" als slotluik van de nieuwe cassatierechtspraak over de uitsluiting van onrechtmatig bewijs" (French-language "mother-in-law decision" as the capstone 
for the exclusion of illegally obtained evidence. Comment on the Court of Cassation decision of 12 October 2005), T.Strafr. 2006, 26-31;

V. VEREECKE, "Politionele informatie ontsnapt aan de Antigoon-toets" (comment on Court of Cassation decision 28 Februari 2017), T. Strafr. 2017, n. 4, 269 - 272;

B. VERSTRAETEN, P. VERMOOTE, "De onderzoeksrechter buiten saisine: een (proactieve) cowboy?” (comment to Cass. 10 June 2014), NC 2015, 197-207;

R. VERSTRAETEN, Handboek Strafvordering, (Companion to Criminal Procedure) Antwerpen, Maklu, 2012, 1372 p.;

R. VERSTRAETEN; A.BAILLEUX, “"Het voorstel van een nieuw Wetboek van strafvordering: algemene beginselen en fase van het onderzoek (The proposal for a new CCP: general principles and the investigation stage)”, in: Themis Strafen strafprocesrecht, academiejaar 2018-19, Bruges, Die Keure 2019, 143-186;

R. VERSTRAETEN, S. DE DECKER, “Antigoon sluit de achterpoort, maar opent een raam" (comment to Court of Cassation decision 16 November 2004), T.Strafr. 2005, n. 6, 289-297. 


\section{Additional information and author's declarations (scientific integrity)}

Acknowledgement: The authors want to thank dr. Elise Maes, postdoctoral researcher Institute of Criminal Law, KU Leuven for her remarks and suggestions.

Conflict of interest declaration: the authors confirm that there are no conflicts of interest in conducting this research and writing this article.

Declaration of authorship: all and only researchers who comply the authorship requirements of this article are listed as authors; all coauthors are fully responsible for this work in its entirety.

- Frank Verbruggen: conceptualization, methodology, data curation, investigation, writing - original draft, validation, writing - review and editing, final version approval.

- Charlotte Conings: conceptualization, methodology, data curation, investigation, writing - original draft, validation, final version approval.

Declaration of originality: the authors assure that the text here published has not been previously published in any other resource and that future republication will only take place with the express indication of the reference of this original publication; they also attest that there is no third party plagiarism or selfplagiarism. This text has been used as an important general source of information for the contribution at hand and a part of its conclusions have been repeated in VII. Final remarks: S. De Decker, F. Verbruggen, "Across the River and Into the Poisonous Trees. From Exclusion to the Use of Illegally Gathered Evidence in Criminal Proceedings in Belgium", in The XIIIth World Congress of Procedural Law: the Belgian and Dutch Reports, Antwerpen, Intersentia, 2008, 63-90. 
Editorial process information

(http://www.ibraspp.com.br/revista/index.php/RBDPP/about/editorialPolicies)

- Submission date: $15 / 12 / 2020$

- Preliminary control and similarity verification: 06/01/2021

- Review 1: 07/01/2021

- Review 2: 09/01/2021

- Review 3: 22/01/2021

- Editorial decision 1: 02/02/2021

- Correction round 1: 22/02/2021

- Editorial decision 2: 23/02/2021

- Correction round 2: 23/02/2021

- Final editorial decision: 24/02/2021
Editorial team responsible

- Editor-in-chief: 1 (VGV)

- Associated-editor: 1 (KK)

- Reviewers: 3

\section{HOW TO CITE (ABNT BRAZIL):}

VERBRUGGEN, Frank; CONINGS, Charlotte. After zigzagging between extremes, finally common sense? Will Belgium return to reasonable rules on illegally obtained evidence? Revista Brasileira de Direito Processual Penal, Porto Alegre, vol. 7, n. 1, p. 273-310, jan./ abr. 2021. https://doi.org/10.22197/rbdpp.v7i1.500

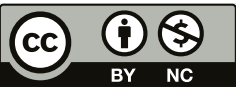

Esta obra está licenciada com uma Licença Creative Commons Atribuição-NãoComercial 4.0 Internacional. 